\title{
Antibacterial Efficiency of Different Irrigation Solutions, Lasers and Photodynamic Therapy with Indocyanine Green in Root Canals Infected By Enterococcus Faecalis
}

\author{
Enterococcus Faecalis ile Enfekte Edilmiş Kök Kanallarında Farkı \\ Irrigasyon Solüsyonlarının, Lazerlerin ve Indosiyanin Yeşili ile \\ Fotodinamik Terapinin Antibakteriyel Etkinliği
}

\author{
(1) İsmail Özkoçak ${ }^{1}$, (1) Hakan Göktürk ${ }^{1}$, (1) Umut Safiye Şay Coşkun ${ }^{2}$, (1) Fatma Aytaç ${ }^{3}$ \\ ${ }^{1}$ Bolu Abant İzzet Baysal University Faculty of Dentistry, Department of Endodontics, Bolu, Turkey \\ ${ }^{2}$ Gaziosmanpaşa University Faculty of Medicine, Department of Medical Microbiology, Tokat, Turkey \\ ${ }^{3}$ Bolu Abant İzet Baysal University Faculty of Dentistry, Department of Restorative Dentistry, Bolu, Turkey
}

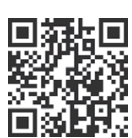

Keywords

Endodontics, Enterococcus faecalis, lasers, photodynamic therapy

Anahtar Kelimeler

Endodonti, Enterococcus faecalis, lazerler, fotodinamik terapi

Received/Geliş Tarihi : 26.07.2017

Accepted/Kabul Tarihi : 06.02.2018

doi:10.4274/meandros.08370

Address for Correspondence/Yazışma Adresi: Hakan Göktürk MD,

Bolu Abant İzzet Baysal University Faculty of Dentistry, Department of Endodontics, Bolu, Turkey

Phone : +90 5056453177

E-mail : gokturk82@hotmail.com

ORCID ID: orcid.org/0000-0003-3824-2569

(C) Meandros Medical and Dental Journal, Published by Galenos Publishing House.

This is article distributed under the terms of the

Creative Commons Attribution NonCommercial 4.0

International Licence (CC BY-NC 4.0).

\section{Abstract}

Objective: The aim of this study was to evaluate bacterial reduction after using different irrigants, lasers and photodynamic therapy (PDT) in root canals infected by Enterococcus faecalis.

Materials and Methods: Seventy human maxillary incisors were used in this study. After endodontic preparation, sixty teeth were infected by $20 \mu \mathrm{l}$. faecalis (ATCC 29212) and specimens were incubated for 72 hours. Groups were formed according to the irrigation protocol used: group 1: negative control, group 2: positive control,

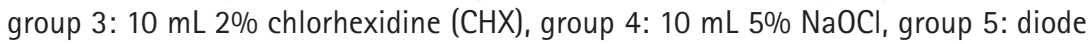
laser, group 6: Er:YAG laser, and group 7: indocyanine green (ICG)-diode laser (PDT). After disinfection procedures the samples isolated from root canals were placed into blood agar, incubated at $37^{\circ} \mathrm{C}$ for $24 \mathrm{~h}$ and then were counted for colony-forming units. One-Way ANOVA was used for the statistical evaluation of data. For multiple comparisons, Tamhane's T2 test was used.

Results: All investigated disinfection procedures had a significant reduction in the bacterial population $(\mathrm{p}<0.001)$. $\mathrm{CHX}, \mathrm{NaOCl}$ and ICG-diode laser groups were equally effective in reducing $E$. faecalis populations ( $p>0.05)$ and statistically more effective than both laser groups $(p<0.05)$.

Conclusion: Promising results were obtained by using PDT with ICG. This alternative disinfection method found effective on $E$. faecalis.

Öz

Amaç: Bu çalışmanın amacı, Enterococcus faecalisile enfekte edilmiş kök kanallarında farklı irrigasyon solüsyonları, lazerler ve fotodinamik tedavi (FDT) kullandıktan sonra bakteri sayısındaki azalmayı değerlendirmektir.

Gereç ve Yöntemler: Bu çalışmada yetmiş adet insan üst çene kesici dişi kullanıldı. Kök kanal preparasyonundan sonra altmış diş $20 \mu \mathrm{L}$ E. faecalis (ATCC 29212) ile 
enfekte edildi ve numuneler 72 saat inkübasyona bırakıldı. Gruplar, kullanılan dezenfeksiyon protokolüne göre oluşturuldu: grup 1: Negatif kontrol, grup 2: Pozitif kontrol, grup 3: $10 \mathrm{~mL} \% 2$ klorheksidin (KH), grup 4: $10 \mathrm{~mL} \% 5 \mathrm{NaOCl}$, grup 5: Diyot lazer, grup 6: Er:YAG lazer ve grup 7: İndosiyanin yeşili (iSY)-diyot lazer (FDT). Dezenfeksiyon prosedürlerinden sonra kök kanallarından izole edilen numuneler kanlı agara yerleştirildi, $37^{\circ} \mathrm{C}^{\prime}$ de 24 saat inkübe edildi ve daha sonra koloni oluşturan birimler sayıldı. Verilerin istatistiksel değerlendirilmesi için tek yönlü varyans analizi, çoklu karşılaştırmalar için Tamhane'nin T2 testi kullanıldı.

Bulgular: Incelenen tüm dezenfeksiyon prosedürleri bakteri popülasyonunda belirgin bir azalmaya neden olmuştur $(p<0,001)$. $\mathrm{KH}$, $\mathrm{NaOCl}$ ve isY-diyot lazer grupları, E. faecalis popülasyonlarının azaltılmasında eşit derecede $(p>0,05)$, her iki lazer grubundan ise istatistiksel olarak anlamlı seviyede daha etkindi $(p<0,05)$.

Sonuç: isY'nin kullanıldığı FDT'de umut verici sonuçlar elde edildi. Bu alternatif dezenfeksiyon yöntemi $E$. faecalis üzerinde etkili bulundu.

\section{Introduction}

The main objective of endodontic therapy is to eliminate pathogenic microorganisms which are the major confounding factor in the treatment of infected root canals and periapical healing (1).

Disinfection of dentinal tubules, accessory canals, isthmuses and ramifications that can be found in root canal system is not possible by mechanical preparation alone (2). Therefore, irrigation is one of the most important steps of endodontic treatment, which is recommended both before and during root canal shaping because of the antibacterial effects and necrotic tissue dissolving properties (3). The most commonly used irrigant in root canal therapy is sodium hypochlorite $(\mathrm{NaOCl})$. Concentrations between $0.5 \%$ and $6 \%$ are preferred (4). Two-percent chlorhexidine (CHX) gluconate is an alternative endodontic solution (5).

The prevalence of endodontic infections depends on microorganisms' ability to adapt to environmental changes. Many different mechanisms are used by bacteria including biofilm formation, physiological modifications, exchange of genetic materials and formation of cell subpopulations (6). Despite the technological and scientific advances in endodontics, there are many unsuccessful cases due to microbial factors. Enterococcus faecalis is the most commonly isolated bacteria in teeth with apical periodontitis and is thought to be responsible for the majority of failed root canal treatments (7). E. faecalis may penetrate up to depths of $400-1000 \mu \mathrm{m}$ in the dentin tubules, can live in conditions with poor nutrition and can develop resistance to root canal disinfectants (8).

Endodontic disinfectants have toxic and inadequate inorganic tissue dissolving properties, can not completely eliminate bacteria and cannot be tolerated by periapical tissues when extruded from apex (9). These factors have prompted researchers to develop novel methods and materials for endodontic procedures (10-13).

Photodynamic therapy (PDT) shows promise as an antimicrobial therapy that can eliminate microorganisms observed in root canal infections. The PDT utilizes a non-toxic photosentizing agent that has the capacity to generate highly reactive species, which are harmful for microorganisms and then irradiates through the application of the laser $(14,15)$.

Recently used methylene blue and toluidine blue as photoactive agents were shown to cause discoloration of anterior teeth $(12,16)$. Indocyanine green (ICG) is a photosensitizing agent that recently developed and used in many areas of medicine $(17,18)$. Previous studies have reported that ICG did not lead to discoloration of teeth and did not produce any toxic or allergic effects. ICG displayed a strong adhesion to bacterial membranes (Porphyromonas gingivalis, Prevotella intermedia, Fusobacterium nucleatum, Tannerella forsythia, Camphylobacter recta, Eikenella corrodens and Treponema denticola) and demonstrated bactericidal effect when activated by a diode laser (19-21).

The aim of present study was to evaluate antibacterial effect of different irrigation solutions, two types of laser and PDT with ICG in infected root canals by $E$. faecalis. The null hypothesis tested was that these disinfection protocols had no influence on the eradication of $E$. faecalis.

\section{Materials and Methods}

The study was reviewed and approved by the Ethics Committee of Gaziosmanpaşa University Faculty of Medicine (approval number: 14-KAEK-246). Seventy human maxillary incisors were used in this study. Mesio-distal and bucco-lingual direction radiographs 
were taken from the teeth to confirm the presence of a single canal. Teeth were decoronated and $15 \mathrm{~mm}$ long roots were obtained, approximately $15 \mathrm{~mm}$ in length. Roots were prepared up to protaper F3 file (Dentsply-Maillefer, Ballaigues, Switzerland). After each file, $2 \mathrm{~mL}$ of $5 \% \mathrm{NaOCl}$ (Whitedentmed, Erhan Kimya, İzmir, Turkey) was used. Five $\mathrm{mL}$ of $5 \% \mathrm{NaOCl}$, $5 \mathrm{~mL}$ of $15 \%$ ethylenediaminetetraacetic acid (Imicryl, Konya, Turkey) and $5 \mathrm{~mL}$ of $5 \% \mathrm{NaOCl}$ solutions were used for the final irrigation respectively. Root canals were dried with paper points. Root apexes were sealed using composite resin. Specimens were placed into Eppendorf tubes with silicone impression material. Teeth were packaged one by one and sterilized in an autoclave at $121{ }^{\circ} \mathrm{C}$ for 30 minutes. After sterilization, 10 teeth were not infected to confirm the accuracy of the sterilization and were evaluated as a negative control group. E. faecalis cultures (ATCC 29212) were incubated for 72 hours and were placed in Brain Heart Infusion broth medium. Solution was prepared to be $0.5 \mathrm{Mc}$ Farland. Each sample was inoculated with $20 \mu \mathrm{L}$ of the prepared solution and specimens were incubated at $37{ }^{\circ} \mathrm{C}$ for 72 hours in the incubator. No disinfection procedure was applied to 10 samples, which were evaluated as the positive control group. In all experimental steps after sterilization samples were handled with sterile gloves, gauze and instruments in a laminar flow chamber to avoid contamination. Groups were formed as follows:

Group 1: Negative control $(n=10)$. Specimens were sterilized and were not infected by $E$. faecalis.

Group 2: Positive control $(n=10)$. Specimens were infected by $E$. faecalis but did not have a disinfection technique applied.

Group 3: $\mathrm{CHX}(\mathrm{n}=10)$. Root canals were irrigated with $10 \mathrm{~mL} 2 \% \mathrm{CHX}$ and $10 \mathrm{~mL}$ sterilized distilled water, respectively.

Group 4: $\mathrm{NaOCl}(n=10)$. Root canals were irrigated with $10 \mathrm{~mL} 5 \% \mathrm{NaOCl}$ and $10 \mathrm{~mL}$ sterilized distilled water, respectively.

Group 5: Diode laser $(n=10)$. Root canals were irradiated for 1 minute with a $940 \mathrm{~nm}$ wavelength diode laser (Epic, Biolase Tech., CA, USA) at 1W power utilizing the continuous mode with endodontic tips.

Group 6: Er:YAG (Erbium Yttrium Aluminium Garnet laser) ( $n=10)$. Root canals were irradiated for 1 minute with a $2940 \mathrm{~nm}$ wavelength Er:YAG laser (Kavo Key 3+, KaVo, Biberach, Germany) with endodontic tips (diameter ISO 30). Laser Parameters were 1W, 10 $\mathrm{Hz}$, and $100 \mathrm{~mJ}$.

Group 7: ICG-diode laser ( $n=10) .25 \mathrm{mg}$ sterile ICG mixed with $5 \mathrm{~mL}$ sterile distilled water in a sterile bottle. Each root canal was irrigated with $0.5 \mathrm{~mL}$ ICG solution then allowed to sit for 30 seconds. Then root canals were then irradiated for 1 minute (30 seconds wet, 30 seconds dry) with a $940 \mathrm{~nm}$ wavelength diode laser (Epic, Biolase Tech., CA, USA) at 1W power using the continuous mode setting with endodontic tips (diameter $200 \mu \mathrm{m}$ ).

Three sterile paper points for each tooth were moistened with $0.5 \mathrm{~mL}$ of sterile distilled water and were placed into the root canal one by one for 1 minute. Paper points were placed into sterile Eppendorf tubes with brain heart infusion medium and specimens were sent to the microbiology laboratory. Vortexing was performed on samples and $20 \mu \mathrm{L}$ of liquid medium was inoculated on blood agar plates. Specimens were incubated at $37^{\circ} \mathrm{C}$ for 24 hours and the colony-forming units (CFU) were counted at the end of incubation. Written consent wasn't obtained because operation was made on extracted teeth.

\section{Statistical Analysis}

One-Way ANOVA was used to evaluate the data. For multiple comparisons, Tamhane's T2 test was used. The significance was defined as $p<0.05$. Analyses were performed using SPSS 19.0 (IBM SPSS Statistics 19, SPSS inc., an IBM Co., Somers, NY, USA).

\section{Results}

Results were summarized in Tables 1 and 2 and Figure 1 . The highest bacterial colonization was observed in the positive control group. While there was no difference between negative control, $\mathrm{NaOCl}$ and the ICG-diode laser groups ( $p>0.05$ ), there were statistical differences between the negative control and all other groups $(p<0.05)$. There was no statistical difference between Er:YAG laser and diode laser groups ( $p>0.05)$. There were no statistically significant difference between $\mathrm{CHX}, \mathrm{NaOCl}$ and PDT (ICG-diode laser) groups ( $p>0.05)$; bacterial colonization has been shown to be decreased when compared with laser groups used alone. Positive and negative bacterial growth three days after disinfection procedures were completed and are shown in Table 2. Laser groups did not completely eliminate $E$. faecalis, despite being quite effective in reducing bacterial colonization. 


\begin{tabular}{|c|c|c|}
\hline Groups & $\begin{array}{l}\text { CFU/mL } \\
\text { Mean } \pm \text { SD }\end{array}$ & $\mathbf{p}$ \\
\hline Negative control & $0.00 \pm 0.00^{\mathrm{A}}$ & \multirow{7}{*}{$<0.001$} \\
\hline Positive control & $8200 \pm 3794.73^{D}$ & \\
\hline Chlorhexidine & $9.40 \pm 7.07^{\mathrm{B}}$ & \\
\hline Sodium hypochlorite & $6.90 \pm 15.37^{A, B}$ & \\
\hline Diode laser & $86.20 \pm 29.55^{c}$ & \\
\hline Er:YAG laser & $67.20 \pm 37.83^{c}$ & \\
\hline ICG-diode laser (PDT) & $7.20 \pm 10.16^{\mathrm{A}, \mathrm{B}}$ & \\
\hline \multicolumn{3}{|c|}{$\begin{array}{l}\text { The results were considered statistically significant for } p<0.05 \text {. } \\
\text { For groups different uppercase letters (A,B,C,D) (One-Way } \\
\text { ANOVA) indicate a statistically significant difference, SD: Standard } \\
\text { deviation, CFU: Colony-forming units, ICG: Indocyanine green, } \\
\text { PDT: Photodynamic therapy }\end{array}$} \\
\hline
\end{tabular}

\begin{tabular}{|l|l|l|}
\hline $\begin{array}{l}\text { Table 2. Bacterial growth after three days from } \\
\text { disinfection of root canal system }\end{array}$ \\
\hline Groups & $\begin{array}{l}\text { Negative growth- } \\
\text { count (n) }\end{array}$ & $\begin{array}{l}\text { Positive growth- } \\
\text { count (n) }\end{array}$ \\
\hline Negative control & 10 & 0 \\
\hline Positive control & 0 & 10 \\
\hline Chlorhexidine & 2 & 8 \\
\hline Sodium hypochlorite & 7 & 3 \\
\hline Diode laser & 0 & 10 \\
\hline Er:YAG laser & 0 & 10 \\
\hline ICG-diode laser (PDT) & 6 & 4 \\
\hline ICG: Indocyanine green, PDT: Photodynamic therapy \\
\hline
\end{tabular}

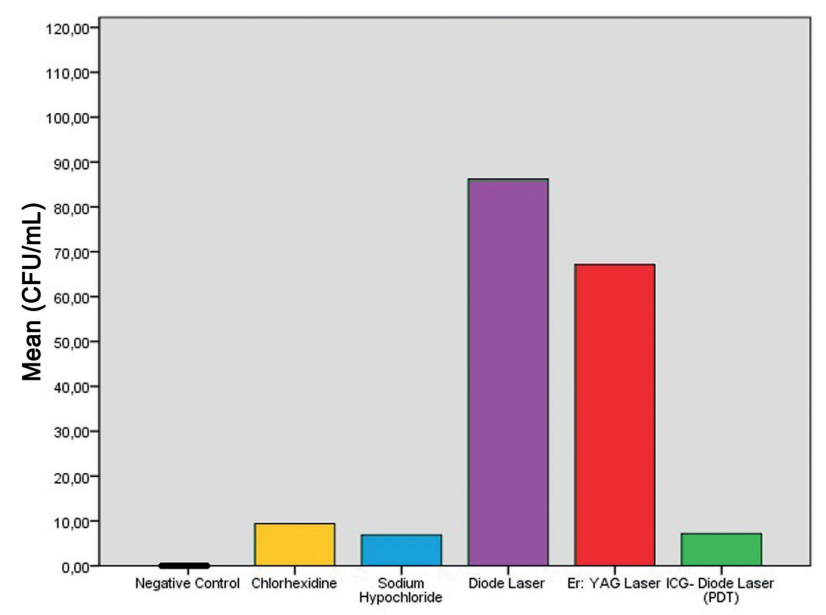

Figure 1. Graphic view of the results. The number of viable $E$. faecalis after each disinfection protocole was counted CFU: Colony-forming units, ICG: Indocyanine green, PDT: Photodynamic therapy
Positive bacterial growth was observed in 10 samples from both the Er:YAG and diode laser groups. There were no bacterial growth in 7 samples in the $\mathrm{NaOCl}$ group, 6 samples in the ICG-diode laser group, and 2 samples from $\mathrm{CHX}$ group.

\section{Discussion}

Irrigation in addition to mechanical preparation is required in order to increase the efficiency of preparation and effectively eliminate bacteria from the root canal system (22). These irrigation solutions should eliminate endodontic pathogens, persistent infection and resistant bacteria. For this purpose, many solutions and their various concentrations and different disinfection methods are used in clinics and research (11,23-26).

However, the cytotoxic properties of the solutions beside antibacterial activity have prompted researchers to seek other options (27). Recently, new systems and materials have been proposed to replace the traditional chemomechanical process or supporting their impact to improve root canal disinfection (28). We aimed to demonstrate the effects of two types of lasers used alone and PDT with ICG on E. faecalis by comparison with conventional endodontic disinfectants. According to our results, $\mathrm{NaOCl}$, ICG-diode laser group and $\mathrm{CHX}$ were more effective in eliminating $E$. faecalis than Er:YAG laser and diode laser disinfection methods. Therefore, the null hypothesis that the eradication of $E$. faecalis was not affected by the disinfection protocols was rejected.

Various studies have reported the antibacterial efficacy of PDT and have stated that PDT can be used safely without harming the host tissue (29-36).

Bonsor et al. (29) compared antimicrobial effect of PDT and $2.5 \% \mathrm{NaOCl}$ on facultative anaerobic microorganisms on patients who were diagnosed irreversible pulpitis or periradicular periodontitis. Tolonium chloride as a photosensitizer and a diode laser as a light source were used. Researchers reported that $2.5 \% \mathrm{NaOCl}$ provided an $80.9 \%$ bacterial reduction whereas PDT caused a bacterial elimination rate of $91.3 \%$ (29).

Fimple et al. (30) evaluated the effects of PDT application with methylene blue and a diode laser at the $665 \mathrm{~nm}$ wavelength in experimentally infected root canals by Actinomyces israeli, F. nucleatum, 
P. gingivalis and P. intermedia and found an $80 \%$ bacterial decrease of CFUs. The findings of the study demonstrated that bacterial elimination could be achieved by more than $1 \log ^{10}$ with an increasing concentration of methylene blue and light energy. Authors have concluded that PDT effectively helps the standard disinfection process with optimized parameters (30).

In another study that used conjugates of polyethyleneimine and chlorine as a photosensitizer with a $660 \mathrm{~nm}$ wavelength diode laser with $40 \mathrm{~mW}$ energy as a light source, Garcez et al. (31) investigated the effects of PDT on antibiotic resistant microflora and retreatment of necrotic pulp teeth. Authors reported that using PDT after traditional chemomechanical preparation provided a microorganism-free root canal system and suggested the use of PDT in the presence of multi-drug-resistant organisms (31).

Pagonis et al. (32) evaluated the effects of PDT with nanoparticles loaded with methylene blue and a $665 \mathrm{~nm}$ wavelength diode laser on E. faecalis in the planktonic phase and reported that application of PDT led to a 1-2 $\log ^{10}$ bacterial reduction in CFUs (32).

Rios et al. (33) evaluated the antimicrobial effect of PDT with toluidine blue and a $638 \mathrm{~nm}$ wavelength light source on root canals infected by $E$. faecalis. They found that PDT resulted in a reduction of the bacterial count and suggested that PDT be used as a supportive antimicrobial process (33). The aforementioned study results are in agreement with this study results.

Nagayoshi et al. (34) studied the antimicrobial effects of PDT with ICG and an $805 \mathrm{~nm}$ wavelength diode laser at $5 \mathrm{~W}$ power in root canals infected by $E$. faecalis by using in vitro apical periodontitis models. The authors concluded that the diode laser irradiation combined with photosensitizer provided closer antimicrobial effect as obtained with 2.5\% $\mathrm{NaOCl}$ and 60 seconds irradiation was more effective than 30 seconds (34). Similarly, Silva et al. (12) used a $660 \mathrm{~nm}$ wavelength diode laser at $40 \mathrm{~mW}$ power with methylene blue and malachite green as photosensitizing agents to evaluate disinfection of root canals by PDT. Authors suggested performing PDT with a diode laser and concluded that both photosensitizers for 60 and 120 seconds created more effective antibacterial effect against the E. faecalis than 30 seconds. (12). Therefore, in the present study, ICG solution was irradiated with a diode laser for 60 seconds in order to more closely simulate an actual clinical application period.

Souza et al. (35) examined the antimicrobial effects of PDT on E. faecalis by using methylene blue and toluidine blue as photosensitizers combined with $\mathrm{NaOCl}$ or sodium chloride and a $660 \mathrm{~nm}$ wavelength diode laser at $40 \mathrm{~mW}$ power as the light source. Authors concluded that PDT application in addition to traditional chemomechanical preparation and irrigation reduced populations of $E$. faecalis in root canals although the decrease was not statistically significant (35). These results are in contrast to the results of the present study. The difference in results may be attributed to the performed disinfection procedures and the used photosensitizer.

Juric et al. (36) investigated the antimicrobial efficacy of PDT in addition to retreatment. Researchers completed the endodontic therapy in a single session after using phenothiazine chloride photosensitizer and a $660 \mathrm{~nm}$ wavelength diode laser at $100 \mathrm{~mW}$ power in addition to chemomechanic preparation. Authors reported that PDT's use in combination with traditional chemomechanical root canal preparation led to significantly greater reductions of CFUs to indicate a decrease of the remaining bacteria or, in some cases, completely eliminated bacteria (36).

PDT was applied in dental practice in different wavelengths (between 488-906 nm) (14,37). A new $940 \mathrm{~nm}$ wavelength diode laser and ICG were used in the present study. As can be understood from our literature review, the role of PDT in the endodontic disinfection process had been tested with the use of the different photosensitizers, light sources and different laser parameters resulting in promising data indicating a reduction of $E$. faecalis in root canals. The results of the present study are consistent with what the researchers mentioned above found. PDT led to significantly higher bacterial reduction when compared with the diode laser group used alone and increased efficiency of the diode laser. However there was not a statistically significant difference in bacterial elimination when PDT was compared with traditional irrigants ( $5 \% \mathrm{NaOCl}$ and $2 \% \mathrm{CHX})$.

Bago et al. (38) examined the antimicrobial activities of PDT and the traditional root canal disinfection techniques in $E$. faecalis infected root canals. For PDT applications, toluidine blue was used as a photosensitizer with a $660 \mathrm{~nm}$ wavelength diode 
laser with $100 \mathrm{~mW}$ power was used in one group. Phenothiazine chloride as a photosensitizer and a 660 $\mathrm{nm}$ wavelength diode laser with $100 \mathrm{~mW}$ power was used in the other group. According to the findings of the study, PDT had the capacity to eradicate $E$. faecalis and is superior to traditional disinfection of $2.5 \% \mathrm{NaOCl}$ (38). Although Bago et al. (38) found outstanding antibacterial activity following use of PDT when compared with $\mathrm{NaOCl}$, their results partially coincide with present study results. In the present study, PDT was found to have the capacity to eliminate $E$. faecalis in serious rate but that PDT showed equivalent antibacterial activity as in $\mathrm{NaOCl}$ and $\mathrm{CHX}$. We conclude that the reasons of this difference are time of application, different laser parameters and type of photosensitizing agent.

Tooth staining and discoloration are the main concerns of PDT, prompting the evaluation of the effectiveness of chemical components in an attempt to overcome this disadvantage. Carvalho Edos et al. (39) found an effective methodology to prevent tooth discoloration caused by methylene blue during PDT by using endo-PTC cream (10\% urea peroxide, 15\% tween 80 and $75 \%$ carbowax). The results of the present study showed that ICG did not lead to any visible tooth discoloration during the current application.

The in vitro model and using planktonic bacteria are the major limitations of this study. Unlike as in our model system, endodontic infections are typically polymicrobial by nature and have interactions between various microorganisms. Because of this, an in vitro culture may not reflect the in vivo condition and biofilm formation may affect results.

\section{Conclusion}

$\mathrm{NaOCl}$ is an irrigant that most commonly used in endodontics, easily available and inexpensive. Besides, $\mathrm{NaOCl}$ cannot be tolerated by periapical tissues and cytotoxic properties of $\mathrm{NaOCl}$ is disadvantage. Promising results were obtained by using PDT with ICG. ICG increased bacterial effectiveness of diode laser. There is need for further in vivo studies to support the in vitro promising results.

\section{Ethics}

Ethics Committee Approval: The study was reviewed and approved by the Ethics Committee of Gaziosmanpaşa University Faculty of Medicine (project number: 14-KAEK-246).
Informed Consent: Written consent wasn't obtained because operation was made on extracted teeth.

Peer-review: External and internal peer-reviewed.

\section{Authorship Contributions}

Concept: I.Ö., Material: I.Ö., H.G., U.S.Ş.C., F.A., Design: i.Ö., H.G., Data Collection or Processing: i.Ö., H.G., U.S.Ş.C., F.A., Analysis or Interpretation: I.Ö., H.G., U.S.Ş.C., F.A, Literature Search: I.Ö., H.G., F.A., Writing: i.Ö., H.G.

Conflict of Interest: No conflict of interest was declared by the authors.

Financial Disclosure: This study was supported by Scientific Research Projects Commission of the Gaziosmanpaşa University, Turkey (2015/132).

\section{References}

1. Xhevdet A, Stubljar D, Kriznar I, Jukic T, Skvarc M, Veranic P, et al. The disinfecting efficacy of root canals with laser photodynamic therapy. J Lasers Med Sci 2014; 5: 19-26.

2. Vivacqua-Gomes N, Gurgel-Filho ED, Gomes BP, Ferraz CC, Zaia AA, Souza-Filho FJ. Recovery of Enterococcus faecalis after single- or multiple-visit root canal treatments carried out in infected teeth ex vivo. Int Endod J 2005; 38: 697-704.

3. Rald DP, Lage-Marques JL. In vitro evaluation of the effects of the interaction between irrigating solutions, intracanal medication and Er:YAG laser in dentin permeability of the endodontic system. Braz Oral Res 2003; 17: 278-85.

4. Zehnder M. Root canal irrigants. J Endod 2006; 32: 389-98.

5. Basrani B, Lemonie C. Chlorhexidine gluconate. Aust Endod J 2005; 31: 48-52.

6. Chavez de Paz LE. Redefining the persistent infection in root canals: possible role of biofilm communities. J Endod 2007; 33: 652-62.

7. Pinheiro ET, Gomes BP, Ferraz CC, Sousa EL, Teixeira FB, SouzaFilho FJ. Microorganisms from canals of root-filled teeth with periapical lesions. Int Endod J 2003; 36: 1-11.

8. Haapasalo $M$, Orstavik D. In vitro infection and disinfection of dentinal tubules. J Dent Res 1987; 66: 1375-79.

9. Ok E, Adanir N, Hakki S. Comparison of cytotoxicity of various concentrations origanum extract solution with $2 \%$ chlorhexidine gluconate and 5.25\% sodium hypochlorite. Eur J Dent 2015; 9: 6-10.

10. Zan R, Hubbezoglu I, Sumer Z, Tunc T, Tanalp J. Antibacterial effects of two different types of laser and aqueous ozone against Enterococcus faecalis in root canals. Photomed Laser Surg 2013; 31: 150-54.

11. Olivi G, DiVito E, Peters O, Kaitsas V, Angiero F, Signore A, Benedicenti S. Disinfection efficacy of photon-induced photoacoustic streaming on root canals infected with Enterococcus faecalis: an ex vivo study. J Am Dent Assoc 2014; 145: 843-48. 
12. Silva EJ, Coutinho-Filho WP, Andrade AO, Herrera DR, CoutinhoFilho TS, Krebs RL. Evaluation of photodynamic therapy using a diode laser and different photosensitizers against enterococcus faecalis. Acta Odontol Latinoam 2014; 27: 63-65.

13. Guneser MB, Arslan D, Usumez A. Tissue dissolution ability of sodium hypochlorite activated by photon-initiated photoacoustic streaming technique. J Endod 2015; 41: 729-32.

14. Gursoy H, Ozcakir-Tomruk C, Tanalp J, Yilmaz S. Photodynamic therapy in dentistry: a literature review. Clin Oral Investig 2013; 17: $1113-25$.

15. Chrepa V, Kotsakis GA, Pagonis TC, Hargreaves KM. The effect of photodynamic therapy in root canal disinfection: a systematic review. J Endod 2014; 40: 891-98.

16. Shrestha A, Kishen A. Antibiofilm efficacy of photosensitizerfunctionalized bioactive nanoparticles on multispecies biofilm. J Endod 2014; 40: 1604-10.

17. Sheth RA, Heidari P, Esfahani SA, Wood BJ, Mahmood U. Interventional optical molecular imaging guidance during percutaneous biopsy. Radiology 2014; 271: 770-77.

18. Samorani D, Fogacci T, Panzini I, Frisoni G, Accardi FG, Ricci M, et al. The use of indocyanine green to detect sentinel nodes in breast cancer: a prospective study. Eur J Surg Oncol 2015; 41: 64-70.

19. Parker S. The use of diffuse laser photonic energy and indocyanine green photosensitiser as an adjunct to periodontal therapy. Br Dent J 2013; 215: 167-71.

20. Nagahara A, Mitani A, Fukuda M, Yamamoto H, Tahara K, Morita $\mathrm{I}$, et al. Antimicrobial photodynamic therapy using a diode laser with a potential new photosensitizer, indocyanine greenloaded nanospheres, may be effective for the clearance of Porphyromonas gingivalis. J Periodontal Res 2013; 48: 591-99.

21. Borchers R. Photodynamic therapy with the new active ingredient Perio Green. Laser 2013; 5: 26-8.

22. Rahimi S, Janani M, Lotfi M, Shahi S, Aghbali A, Vahid Pakdel M, Salem Milani A, Ghasemi N. A review of antibacterial agents in endodontic treatment. Iran Endod J 2014; 9: 161-68.

23. Baker NE, Liewehr FR, Buxton TB, Joyce AP. Antibacterial efficacy of calcium hydroxide, iodine potassium iodide, betadine, and betadine scrub with and without surfactant against $E$ faecalis in vitro. Oral Surg Oral Med Oral Pathol Oral Radiol Endod 2004; 98: 359-64.

24. Kustarci A, Sumer Z, Altunbas D, Kosum S. Bactericidal effect of KTP laser irradiation against Enterococcus faecalis compared with gaseous ozone: an ex vivo study. Oral Surg Oral Med Oral Pathol Oral Radiol Endod 2009; 107: 73-79.

25. Neelakantan P, Cheng CQ, Mohanraj R, Sriraman P, Subbarao C, Sharma S. Antibiofilm activity of three irrigation protocols activated by ultrasonic, diode laser or Er:YAG laser in vitro. Int Endod J 2015; 48: 602-10.

26. Kayaoglu G, Omurlu H, Akca G, Gurel M, Gencay O, Sorkun K, et al. Antibacterial activity of Propolis versus conventional endodontic disinfectants against Enterococcus faecalis in infected dentinal tubules. J Endod 2011; 37: 376-81.

27. Prado M, Silva EJ, Duque TM, Zaia AA, Ferraz CC, Almeida JF, et al. Antimicrobial and cytotoxic effects of phosphoric acid solution compared to other root canal irrigants. J Appl Oral Sci 2015; 23: 158-63.

28. Siqueira JF Jr., Rocas IN. Optimising single-visit disinfection with supplementary approaches: a quest for predictability. Aust Endod J 2011; 37: 92-98.

29. Bonsor SJ, Nichol R, Reid TM, Pearson GJ. An alternative regimen for root canal disinfection. Br Dent J 2006; 201: 101-05.

30. Fimple JL, Fontana CR, Foschi F, Ruggiero K, Song X, Pagonis TC, et al. Photodynamic treatment of endodontic polymicrobial infection in vitro. J Endod 2008; 34: 728-34.

31. Garcez AS, Nunez SC, Hamblim MR, Suzuki H, Ribeiro MS. Photodynamic therapy associated with conventional endodontic treatment in patients with antibiotic-resistant microflora: a preliminary report. J Endod 2010; 36: 1463-66.

32. Pagonis TC, Chen J, Fontana CR, Devalapally H, Ruggiero K, Song $X$, et al. Nanoparticle-based endodontic antimicrobial photodynamic therapy. J Endod 2010; 36: 322-28.

33. Rios A, He J, Glickman GN, Spears R, Schneiderman ED, Honeyman AL. Evaluation of photodynamic therapy using a lightemitting diode lamp against Enterococcus faecalis in extracted human teeth. J Endod 2011; 37: 856-59.

34. Nagayoshi M, Nishihara T, Nakashima K, Iwaki S, Chen KK, Terashita $\mathrm{M}$, et al. Bactericidal Effects of Diode Laser Irradiation on Enterococcus faecalis Using Periapical Lesion Defect Model. Int Sch Res Notices 2011; 2011: 870364.

35. Souza LC, Brito PR, de Oliveira JC, Alves FR, Moreira EJ, SampaioFilho HR, et al. Photodynamic therapy with two different photosensitizers as a supplement to instrumentation/irrigation procedures in promoting intracanal reduction of Enterococcus faecalis. J Endod 2010; 36: 292-96.

36. Juric IB, Plecko V, Panduric DG, Anic I. The antimicrobial effectiveness of photodynamic therapy used as an addition to the conventional endodontic re-treatment: a clinical study. Photodiagnosis Photodyn Ther 2014; 11: 549-55.

37. Trindade AC, De Figueiredo JA, Steier L, Weber JB. Photodynamic therapy in endodontics: a literature review. Photomed Laser Surg 2015; 33: 175-82.

38. Bago I, Plecko V, Gabric Panduric D, Schauperl Z, Baraba A, Anic I. Antimicrobial efficacy of a high-power diode laser, photoactivated disinfection, conventional and sonic activated irrigation during root canal treatment. Int Endod J 2013; 46: 339-47.

39. Carvalho Edos S, Mello I, Albergaria SJ, Habitante SM, LageMarques JL, Raldi DP. Effect of chemical substances in removing methylene blue after photodynamic therapy in root canal treatment. Photomed Laser Surg 2011; 29: 559-63. 